\title{
PRACTICES AND ATTITUDES OF INDIAN CATCH-AND-RELEASE ANGLERS: IDENTIFYING OPPORTUNITIES FOR ADVANCING THE MANAGEMENT OF RECREATIONAL FISHERIES
}

\author{
Nishikant Gupta ${ }^{1}$, Shannon D. Bower ${ }^{2}$, Steven J. Cooke ${ }^{3}$, Andy J. Danylchuk ${ }^{4}$ \& Rajeev \\ Raghavan $^{5}$
}

\author{
${ }^{1}$ Department of Geography, King's College London, Strand, London WC2R 2LS, United Kingdom \\ ${ }^{2,3}$ Fish Ecology and Conservation Physiology Laboratory, Department of Biology, Carleton University, Ottawa K1S 5B6, \\ ON, Canada \\ ${ }^{4}$ Department of Environmental Conservation, University of Massachusetts Amherst, Amherst MA 01003, MA, USA \\ ${ }^{5}$ Department of Fisheries Resource Management, Kerala University of Fisheries and Ocean Studies (KUFOS), Kochi, \\ Kerala 682506, India \\ ${ }^{5}$ Laboratory of Systematics, Conservation and Ecology, Zoo Outreach Organization (ZOO), 96, Kumudham Nagar, \\ Villankurichi Road, Coimbatore, Tamil Nadu 641035, India \\ ${ }^{5}$ Mahseer Trust, The Freshwater Biological Association, East Stoke River Laboratory, Wareham, Dorset BH20 6BB, \\ United Kingdom \\ ${ }^{1}$ nishikantgupta@live.in (corresponding author), ${ }^{2}$ shannondbower@gmail.com, ${ }^{3}$ steven.cooke@carleton.ca, \\ ${ }^{4}$ danylchuk@eco.umass.edu, ${ }^{5}$ rajeev@kufos.ac.in
}

\begin{abstract}
Recreational fishing, a popular leisure activity, can potentially support conservation of species and provide socio-economic benefits to local economies. Nonetheless, there are ecological concerns regarding this pastime, especially in developing economies such as India where little information is available concerning impacts on fish populations. An online survey targeting recreational anglers practicing catch-and-release $(C \& R)$ in India $(n=200)$ revealed 25 states/union territories as prime angling locations, with Mahseer (Tor spp.) constituting the main target species group (53\%). Angling season (28\%) and pristine river surroundings (14\%) were stated as major factors important for angling, while overfishing (31\%) and the use of illegal fishing techniques were highlighted as chief threats to fish species. Respondents were in favour of strictly adhering to C\&R guidelines (23\%), controlling illegal fishing techniques and pollution (18\%) and spreading awareness and education among local stakeholders (18\%) to protect fish. Over $75 \%$ of respondents were also willing to contribute both their time and money to conservation initiatives focusing on key sport fish. With anglers targeting multiple fishing locations throughout India, there is a need for consistent governance structures and policy instruments to support the development of sustainable recreational fisheries while minimising conflict with other stakeholder groups. The impacts of C\&R fisheries interactions on individuals and populations (especially for threatened species) need to be studied in the Indian context. Direct participation by recreational anglers in C\&R research could strengthen broader conservation and management initiatives throughout the country by increasing stewardship.
\end{abstract}

Keywords: Rivers, socio-economic benefits, sport fishing, stakeholder.

DOI: http://dx.doi.org/10.11609/jott.2410.8.4.8659-8665

Editor: Anonymity requested.

Date of publication: 26 April 2016 (online \& print)

Manuscript details: Ms \# 2410 | Received 12 November 2015 | Final received 08 January 2016 | Finally accepted 28 March 2016

Citation: Gupta, N., S.D. Bower, S.J. Cooke, A.J. Danylchuk \& R. Raghavan (2016). Practices and attitudes of Indian catch-and-release anglers: identifying opportunities for advancing the management of recreational fisheries. Journal of Threatened Taxa 8(4): 8659-8665; http://dx.doi.org/10.11609/jott.2410.8.4.8659-8665

Copyright: (c) Gupta et al. 2016. Creative Commons Attribution 4.0 International License. JoTT allows unrestricted use of this article in any medium, reproduction and distribution by providing adequate credit to the authors and the source of publication.

Funding: SJC is supported by the Canada Research Chairs Program and NSERC. SJC and SDB are further supported by the Too Big to Ignore Network organized by Memorial University and funded through SSHRC. RR is funded by the Center for Taxonomy of Aquatic Animals, a plan project of the Government of Kerala implemented through the Kerala University of Fisheries and Ocean Studies.

Conflict of Interest: The authors declare no competing interests. Funding sources had no role in study design, data collection, results interpretation and manuscript writing. None of the authors or the institutions they are affiliated with, have commercial/business interests in the angling sector in India.

For Author Contribution \& Author Details see end of this article.

Acknowledgements: The authors thank anglers from all over India who participated in this survey through numerous angling forums and social media.
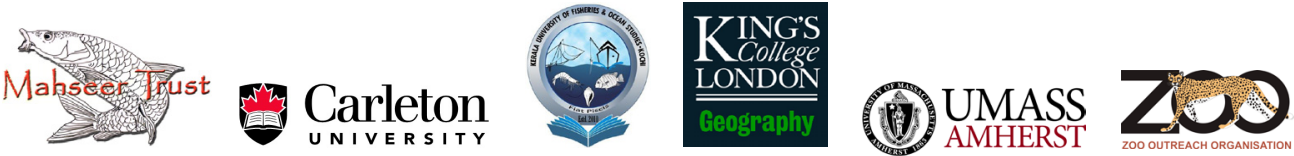


\section{INTRODUCTION}

Recreational fishing, whether to release fish back into the water (i.e., catch-and-release angling; C\&R) or for personal consumption (i.e., sustenance fishing), is widespread in both freshwater and marine ecosystems (FAO 2012). Catch-and-release is a common angling practice in developed countries (Arlinghaus et al. 2007), and is increasing in developing nations (Bower et al. 2014; Barnett et al. 2015). In India, recreational angling dates back to the British Empire, but there has been considerable growth in the last few decades because of increased domestic participation rates and an influx of international anglers (Everard \& Kataria 2011; Pinder \& Raghavan 2013; Gupta et al. 2014, 2015a,b; Pinder et al. 2015).

Catch-and-release angling has the potential to provide socio-economic benefits to local stakeholders (Pereira et al. 2008; Barnett et al. 2015), generate income for national economies (Suski \& Cooke 2007; Cowx et al. 2010; Danylchuk \& Cooke 2011; Everard \& Kataria 2011) and facilitate both species and ecosystem conservation (Arlinghaus 2006; Granek et al. 2008; Pinder \& Raghavan 2013). However, angling may also have negative effects on fish and their habitats (Cooke \& Cowx 2006). In India, little is known regarding the benefits and/or risks to freshwater and marine ecosystems and species due to C\&R angling, and it is therefore a research priority (Gupta et al. 2015a). In this paper, amidst the haze of uncertainty surrounding the potential effects of C\&R angling on target fish species, we examine the practices and attitudes of C\&R anglers in India and identify issues and opportunities that are necessary to realize long-term sustainability in the sector.

\section{MATERIALS AND METHODS}

A web-based survey of Indian C\&R anglers was conducted through a series of questions formulated to obtain data on demographics, angler behaviours, and conservation/management perceptions (see Appendix 1). The survey was deployed over 45 days (from June to July 2014). Consistent with best survey practice, a pilot survey was run among randomly selected respondents prior to data collection to pinpoint any potential problems with the completion of the survey (as recommended by Andrews et al. 2003). Each response collected was thoroughly reviewed to ensure that no individuals submitted multiple responses (as recommended by Hasler et al. 2011). Issues such as security/access/ privacy of collected data were taken into consideration by ensuring strict confidentiality of each response.

To reduce the likelihood of access-based sampling bias and to attract participation from $C \& R$ fishers of varied income groups in India, the survey was promoted as widely as possible on a variety of conservation/angling sites, forums, groups and social media (Facebook/ Twitter). These methods were deemed appropriate as this survey was designed to explore the perceptions of C\&R anglers specifically, who were expected to be well represented online compared to sustenance-based recreational fishers. Nonetheless, we acknowledge some potential for bias towards those with greater IT literacy and access which may also be a surrogate for socioeconomic status; hence, a need to maintain a degree of caution to the survey findings.

Survey questions elicited responses regarding: (a) preferred angling locations; (b) preferred angling techniques; (c) the mean number of days spent angling; (d) preferred target species; (e) the average number of fish caught per year; (f) money spent (INR/year) on recreational angling activities; (g) factors influencing the angling activities; (h) perceived threats to target fish species and fishing locations; (i) conservation strategies anglers felt were needed for the protection of target species; (j) willingness to pay for, and get involved in a conservation initiative in their angling location; (k) anglers' willingness to contribute time and money for such an initiative; (I) destructive fishing techniques in use near the angling location; and ( $m$ ) angler awareness on the conservation status of target fish species. Null responses were not allowed for any of the questions and the percentages of responses calculated are based on the number of completely filled responses only.

\section{RESULTS}

Two-hundred completed responses were obtained from C\&R anglers across India. Fifty-one of the anglers surveyed claimed to return $91-100 \%$ of the fish caught back into the river, which suggests the target group was adequately reached. In addition, 25 of the anglers surveyed returned only internationally renowned target fish species such as the Mahseer (Tor spp.) safely back into the water. As respondents chose to answer some but not all of the questions, the percentages calculated for each question below is based on the number of completely filled responses obtained, (i.e., $n=200$ ). Respondents originated from 28 States/Union Territories of India and were between 14 to 77 years of age (Table 
Table 1. States/Union Territories of residence and preferred fishing locations of respondents

\begin{tabular}{|c|c|c|c|c|c|}
\hline State/Union Territory & $\begin{array}{l}\text { Residents } \\
\text { (n) }\end{array}$ & $\begin{array}{l}\text { Preferred fishing } \\
\text { location }(n)\end{array}$ & State/Union Territory & $\begin{array}{l}\text { Residents } \\
\text { (n) }\end{array}$ & $\begin{array}{l}\text { Preferred fishing } \\
\text { location (n) }\end{array}$ \\
\hline Andaman \& Nicobar & 2 & 6 & Madhya Pradesh & 1 & 3 \\
\hline Andhra Pradesh & 8 & 8 & Maharashtra & 45 & 42 \\
\hline Arunachal Pradesh & 2 & 5 & Meghalaya & 1 & 1 \\
\hline Assam & 6 & 8 & Mizoram & 2 & 2 \\
\hline Bihar & 1 & 0 & Nagaland & 2 & 3 \\
\hline Chandigarh & 2 & 0 & Puducherry & 1 & 1 \\
\hline Delhi & 17 & 0 & Punjab & 2 & 3 \\
\hline Goa & 2 & 6 & Rajasthan & 1 & 2 \\
\hline Gujarat & 1 & 1 & Sikkim & 3 & 5 \\
\hline Haryana & 3 & 4 & Tamil Nadu & 14 & 17 \\
\hline Himachal Pradesh & 6 & 23 & Tripura & 1 & 1 \\
\hline Jammu \& Kashmir & 2 & 2 & Uttar Pradesh & 2 & 1 \\
\hline Karnataka & 46 & 46 & Uttarakhand & 4 & 19 \\
\hline Kerala & 5 & 8 & West Bengal & 18 & 18 \\
\hline
\end{tabular}

1). All respondents were male, with $69 \%$ affiliated with various fishing/angling associations, including $26 \%(n=52)$ belonging to the All India Game Fishing Association (AIGFA). The respondents highlighted 25 States/Union Territories as preferred fishing locations, with a strong preference for states such as Karnataka $(n=46)$, Maharashtra $(n=42)$ and Himachal Pradesh ( $n=23$ ) (Table 1).

Respondents reported bait fishing (51\%), spinning (42\%), and fly fishing (7\%) as their preferred angling methods. The mean number of days spent angling was 40 days/year. By category, the most common number of days spent angling per year was from 0-20 days (28\%), followed by $21-40$ days (25\%; Fig. $1 \mathrm{~A}$ ).

A total of 16 freshwater fish species were caught, of which 53\% anglers in general targeted three Mahseer species: Tor putitora Golden Mahseer, T. khudree Deccan Mahseer and Neolissochilus hexagonolepis Copper or Chocolate Mahseer. In addition, Catla catla (Indian Major Carp/Catla) was targeted by $13 \%$ of anglers. Numerous marine species were also targeted (Fig. 1B), including Caranx ignobilis (Giant Trevally; $\mathrm{n}=11$ ), Cynoglossus macrostomus (Tounge Sole; $\mathrm{n}=4$ ), Gymnosarda unicolor (Dogtooth Tuna; $n=2$ ), Lates calcarifer (Asian Seabass; $\mathrm{n}=33$ ), Sphyraena sp. (Barracuda; $\mathrm{n}=1$ ), and Thunnus obesus (Bigeye Tuna; $\mathrm{n}=1$ )

The number of fishes caught per year in Indian freshwater systems was > 100 (29\%) followed by 0 and 20 fish per year (21\%; Fig. 1C). Nonetheless, such values have to be treated with caution due to challenges associated with angler estimates of catch, and the effectiveness of recall varying according to the timeline for which anglers are expected to recall their catch. Although the numbers are more likely to be inflated for longer recall periods, they are valuable as a first estimate of catch and cannot be overlooked.

Thirty-three percent of respondents spent between 0 and 10,000 INR per year on recreational fishing activities followed by $18 \%$ spending over $>100,000$ INR (Figure 1D). No anglers reported expenditures between 60,000 and 90,000 INR.

Respondents were free to list many factors and considered eight as the most important for angling, among which angling season (28\% of respondents) was the dominant response followed by availability of pristine river surroundings (14\%; Fig. 2A).

With no restrictions on choices made by the anglers, seven major factors were considered as threats to the target species, which included overfishing as the most stated threat ( $31 \%$ of respondents) followed by the use of illegal fishing techniques (26\%; Fig. 2B, also see Table 2).

Anglers freely supported seven possible management approaches to benefit (and protect) target species. The dominant approach was strictly adhering to C\&R practices (23\% of respondents), followed jointly by controlling the use of illegal fishing techniques and pollution (18\%), and spreading awareness and educating local communities living along freshwater bodies about the value of conserving fishery resources (18\%; Fig. 2C).

A majority of the anglers (90\%) were willing to get involved in local conservation initiatives where they fished if opportunities exist, while $8 \%$ were unsure, and $2 \%$ were unwilling to get involved. Further, $67 \%$ of 

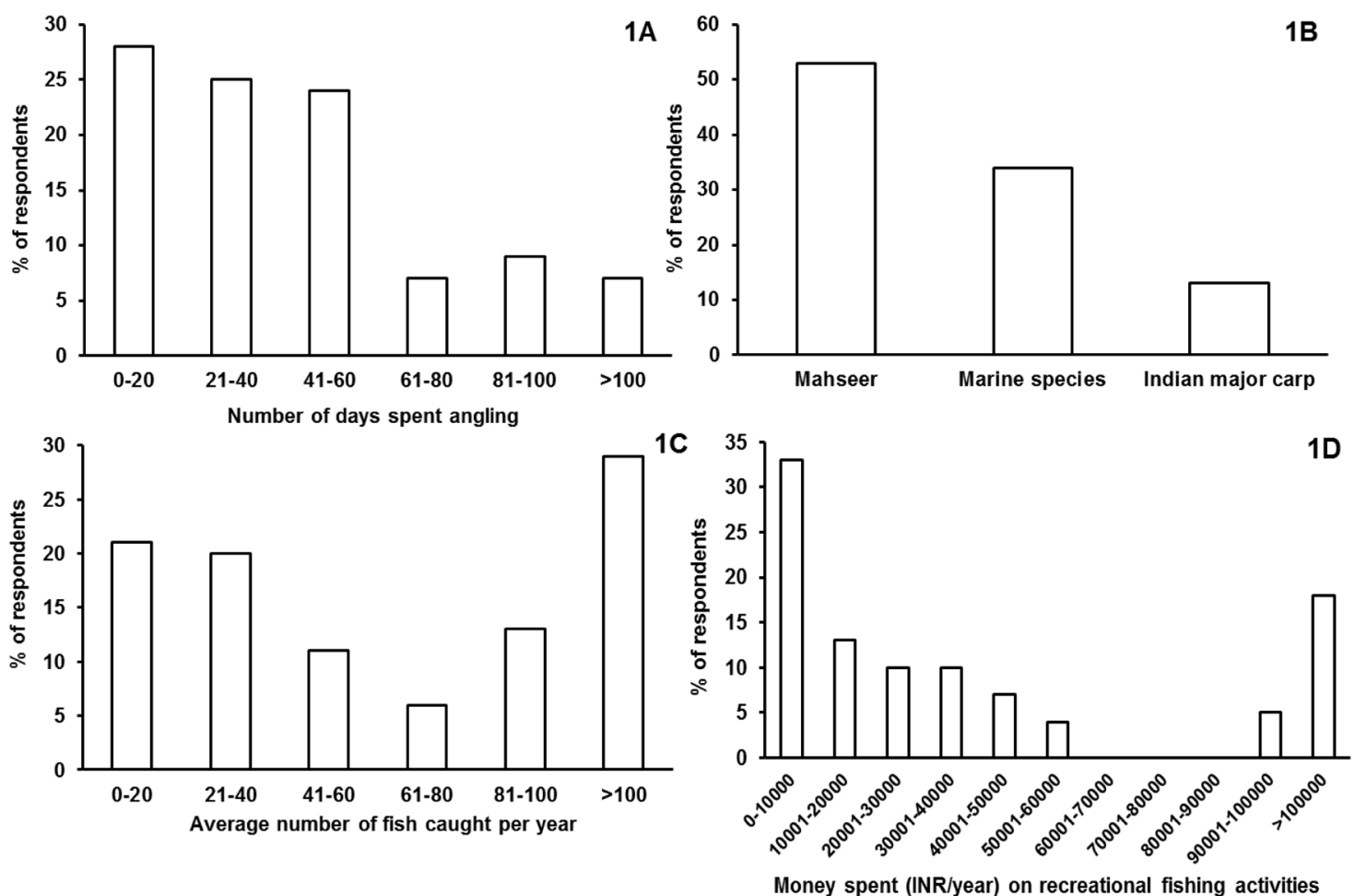

Figure 1. Distribution of responses to angling-species questions (1A: number of days spent angling; 1B: preferred angling fish species; 1C: average number of fish caught/year; 1D: money spent (INR/year) on recreational fishing activities).

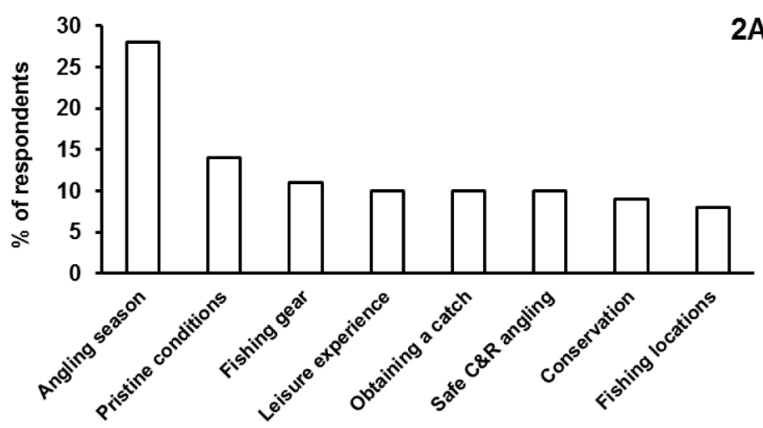

Factors influential to angling activities

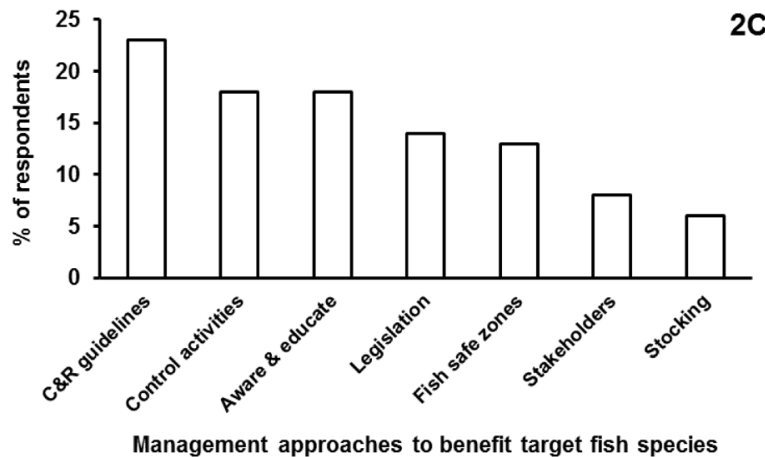

2A

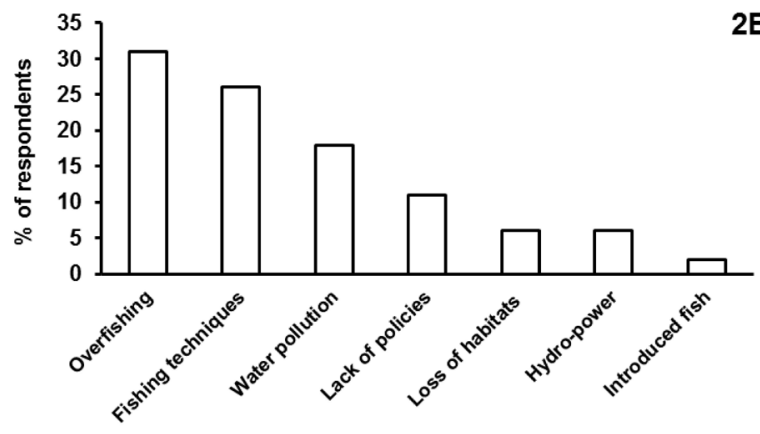

Threats to target fish species

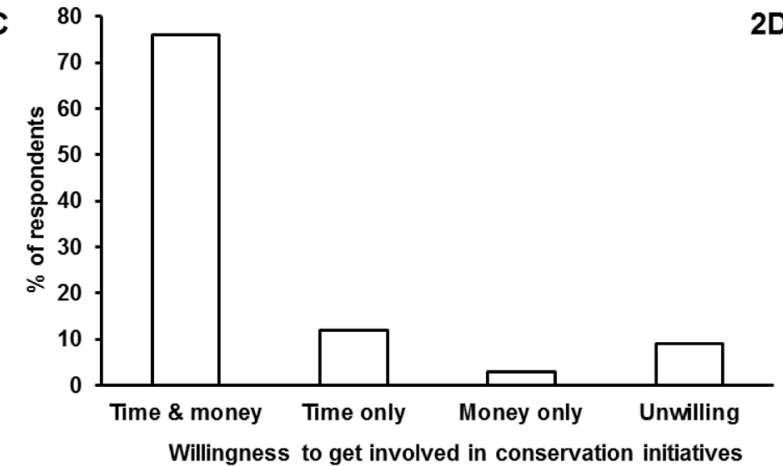

Figure 2. Distribution of responses to questions relating to angler persectives (2A: factors influencing angling activities; 2B: perceived threats to target fish species; 2C: possible management approaches to benefit target fish species; 2D: willingness to get involved in conservation initiatives). 
Table 2. Dominant responses from Indian C\&R anglers regarding the benefits of angling for freshwater fishes, and their associated concerns

\begin{tabular}{|c|c|c|}
\hline Criteria (C\&R angling activities) & Associated benefits of C\&R angling & Important concerns \\
\hline $\begin{array}{l}\text { a) Provides social and economic opportunities } \\
\text { b) Generates funds locally }\end{array}$ & $\begin{array}{l}\text { a) Creates jobs for local stakeholders, and possibly } \\
\text { poachers } \\
\text { b) Funds can support targeted conservation } \\
\text { projects } \\
\text { c) Economic betterment of local communities }\end{array}$ & $\begin{array}{l}\text { a) Lack of government support } \\
\text { b) Urgent need to set up C\&R angling conservation } \\
\text { units within village communities }\end{array}$ \\
\hline $\begin{array}{l}\text { a) Patrolling by anglers during angling activities; } \\
\text { large freshwater reaches covered in search of } \\
\text { target fish species } \\
\text { b) Presence of anglers along river banks during } \\
\text { angling }\end{array}$ & $\begin{array}{l}\text { a) Presence of anglers often keeps poachers away } \\
\text { b) Prevents use of illegal fishing techniques at river } \\
\text { reaches where anglers are camped } \\
\text { c) Prevents boulder and sand mining at times } \\
\text { d) Anglers have reported potential stressors to } \\
\text { local authorities in the past }\end{array}$ & $\begin{array}{l}\text { a) Poachers are seldom dealt with by concerned } \\
\text { authorities } \\
\text { b) No formal protection of critical fish habitats } \\
\text { from anthropogenic threats }\end{array}$ \\
\hline $\begin{array}{l}\text { a) C\&R angling has the potential to be practised as } \\
\text { per environmental guidelines: } \\
\text { (i) Appropriate handing, air exposure and release } \\
\text { of fish } \\
\text { (ii) Type of hook used checked } \\
\text { (iii) Maintaining anglers' logbook }\end{array}$ & $\begin{array}{l}\text { a) Reduce damage to targeted fish species } \\
\text { b) Provide fish data to scientists }\end{array}$ & $\begin{array}{l}\text { a) More scientific studies are needed regarding } \\
\text { C\&R angling within Indian freshwater bodies }\end{array}$ \\
\hline $\begin{array}{l}\text { a) Education and awareness through C\&R angling: } \\
\text { (i) Organizing angling camps, competitions and } \\
\text { prizes } \\
\text { (ii) Involving mass media during such activities }\end{array}$ & $\begin{array}{l}\text { a) Highlighting the importance of freshwater } \\
\text { ecosystem, and generating interest on regional } \\
\text { and national level } \\
\text { b) Anglers as an important local stakeholder group } \\
\text { can influence policies in the long run }\end{array}$ & $\begin{array}{l}\text { a) Public awareness regarding freshwater bodies } \\
\text { and fish is lacking greatly }\end{array}$ \\
\hline
\end{tabular}

respondents were willing to contribute both their time and money for such conservation initiatives, whereas $9 \%$ of the anglers were not interested to spend either their time or money on such initiatives (Fig. 2D).

Eighty-seven percent of anglers had witnessed destructive fishing techniques at/near their angling locations. These included the use of dynamite (36\%), destructive fishing nets (32\%), poisons (14\%), electricity (11\%), and snagging with treble hooks (7\%).

When asked about their awareness of the conservation status (i.e., IUCN Red List status) of the fish species they primarily targeted, $40 \%$ of the respondents were strongly aware, $31 \%$ were aware, $22 \%$ were somewhat aware, and $7 \%$ did not have any knowledge or awareness.

\section{DISCUSSION}

Although we reached only 200 anglers in India with our survey, they represented great diversity in terms of their query and perspectives. Respondents that participated in this survey indicated that the most popular locations for C\&R recreational fisheries in India were the Himalaya (Uttarakhand and Himachal) and the Western Ghats (Karnataka and Maharashtra), with most of the fishing in Maharashtra occurring in hilly regions. These biodiversity hotspots are known for their exceptional freshwater fish diversity and endemism (Vishwanath et al. 2010; Dahanukar et al. 2011), elevating the importance of minimizing impacts of recreational angling as a goal of fisheries management. Unregulated and unmanaged angling without proper guidelines has the potential to harm freshwater ecosystems, such as through the spread of anthropogenic debris and discarded fishing lines, use of invasive species as baits and removal of riparian vegetation to reach angling locations (Gupta et al. 2014; Arlinghaus et al. 2015).

Although a large majority of angling associations in India are registered and catalogue the practice of recreational angling through paid permits, a number of unlicensed angling associations continue to operate in major angling locations (Gupta et al. 2015a). Nonetheless, recently published data obtained from angler log-books in prime angling sites in India (Gupta et al. 2014; Pinder et al. 2015) have indicated that C\&R angling potentially has not resulted in negative impacts on targeted fish populations. A recent study examining the impacts of C\&R on the Blue-finned Mahseer of the Cauvery further supported these findings, concluding that injury and mortality rates resulting from $C \& R$ angling methods are very low for this species (Bower et al. In Press).

The perceptions of respondents towards anthropogenic threats on their target fish species and fishing locations included overfishing, use of illegal fishing techniques, and water pollution, which are in line with existing threats recorded in scientific literature (Dahanukar et al. 2011; Raghavan et al. 2011). This is consistent with the perception of respondents about the most effective management approaches to benefit (and protect) the target species, including strictly adhering to $C \& R$ practices, controlling the use of illegal fishing 
techniques and pollution, spreading awareness, and educating local communities living alongside freshwater bodies.

C\&R and other specialized anglers can be supportive of management initiatives designed to reduce external threats to aquatic ecosystems (Cowx et al. 2010). The results from this survey suggest that this is also true for C\&R anglers in India. This is a promising response, as the interest of anglers in conserving their target habitats and fish species creates potential opportunities for developing participatory and even voluntary enforcement mechanisms (Cooke et al. 2013).

The willingness of anglers to get involved in a local conservation initiative in their angling locations and devote both their time and money is also encouraging, as these resources could be potentially channelled to assist with additional conservation projects. This approach has been adopted through the community-based efforts of the Wildlife Association of South India (WASI) and the Coorg Wildlife Society (CWS) in protecting the Mahseer species through anglers' support (Gupta et al. 2015a). The Himalayan Outback on the Ramganga River has also initiated a community awareness/participation drive to protect the Golden Mahseer, T. putitora, and its habitat. A small contribution from visiting recreational anglers has set the campaign in motion. The broad age range of Indian angler respondents who undertook our survey presents additional potential opportunities to educate the youth (Gupta et al. 2015c) about recreational angling and freshwater ecosystem conservation in India.

A majority of the anglers surveyed highlighted the lack of government support for recreational fisheries in India, as well as the need to set up angling conservation units within village communities to ensure that local stakeholders benefit from the industry (Table 2). This further emphasizes the need for improved governance structures to support the recreational fishing sector in India. This study emphasizes that C\&R activities are occurring in various locations throughout India, and the range of identified behaviours and perspectives suggests that further research into potential benefits and risks associated with C\&R are warranted. Research into the human dimensions of recreational fisheries is a crucial aspect of sustainable management (Hunt et al. 2013) and an important component of any fisheries governance system. Formalized licensing schemes could be used to quantify the popularity of recreational fishing in India and could also be used as a sample frame for more detailed surveys of catch, harvest and preferences (e.g., Brownscombe et al. 2014). Although this survey focused on India, similar information is needed across the developing world and especially in emerging economies where recreational fishing is apparently on the rise.

\section{REFERENCES}

Andrews, D., B. Nonnecke \& J. Preece (2003). Electronic survey methodology: A case study in reaching hard to involve Internet Users. International Journal of Human-Computer Interaction 16: 185-210.

Arlinghaus, R (2006). Overcoming human obstacles to conservation of recreational fishery resources, with emphasis on central Europe. Environmental Conservation 33: 46-59.

Arlinghaus, R., T. Mehner \& I.G. Cowx (2002). Reconciling traditional inland fisheries management and sustainability in industrialized countries, with emphasis on Europe. Fish and Fisheries 3: 261-316.

Arlinghaus, R., S.J. Cooke, J. Lyman, D. Policansky, A. Schwab, C.D. Suski, S.G. Sutton \& E.B. Thorstad (2007).Understanding the complexity of catch-and-release in recreational fishing: an integrative synthesis of global knowledge from historical, ethical, social, and biological perspectives. Reviews in Fisheries Science 15: 75-167.

Arlinghaus, R., K. Lorenzen, B.M. Johnson, S.J. Cooke \& I.G. Cowx (2015). Managing freshwater fisheries: addressing habitat, people and fish, pp. 557-579. In: Craig, J. (ed.). Freshwater Fisheries Ecology. Blackwell Science, UK.

Barnett, A., K.G. Abrantes, R. Baker, A.S. Diedrich, M. Farr, A. Kuilboer, T. Mahony, I. McLeod, G. Moscardo, M. Prideaux, N. Stoeckl, A. van Luyn \& M. Sheaves (2015). Sportfisheries, conservation and sustainable livelihoods: a multidisciplinary guide to developing best practice. Fish and Fisheries http://dx.doi.org/10.1111/faf.12140

Bower, S.D., A.J. Danylchuk, R. Raghavan, S. Clark-Danylchuk, A. Pinder \& S.J. Cooke (In Press). Rapid assessment of the physiological impacts caused by catch-and-release angling on Blue-finned Mahseer (Tor sp.) of the Cauvery River, India. Fisheries Management and Ecology

Brownscombe, J.W., S.D. Bower, W. Bowden, L. Nowell, J.D. Midwood, N. Johnson \& S.J. Cooke (2014). Canadian recreational fisheries: 35 years of social, biological, and economic dynamics from a national survey. Fisheries 39: 251-260.

Cooke, S.J. \& I.G. Cowx (2004). The role of recreational fishing in global fish crises. BioScience 54: 857.

Cooke, S.J. \& I.G. Cowx (2006). Contrasting recreational and commercial fishing: Searcing for common issues to promote unified conservation of fisheries resources and aquatic environments. Biological Conservation, 128: 93-108.

Cooke, S.J., C.D. Suski, R. Arlinghaus \& A.J. Danylchuk (2013). Voluntary institutions and behaviours as alternatives to formal regulations in recreational fisheries management. Fish and Fisheries 14: 439-457.

Cowx, I.G., R. Arlinghaus \& S.J. Cooke (2010). Harmonizing recreational fisheries and conservation objectives for aquatic biodiversity in inland waters. Journal of Fish Biology 76: 2194-2215.

Dahanukar, N., R. Raghavan, A. Ali, R. Abraham \& C.P. Shaji (2011). The status and distribution of freshwater fishes of the Western Ghats, pp. 21-48. In: Molur, S., K.G. Smith, B.A. Daniel \& W.R.T. Darwall (comp.). The Status and Distribution of Freshwater Biodiversity in the Western Ghats, India. IUCN/Zoo Outreach Organization, Cambridge/ Coimbatore, India, viii+116pp.

Danylchuk, A. J., \& S.J. Cooke (2011). Engaging the recreational angling community to implement and manage aquatic protected areas. Conservation Biology 25: 458-64.

Everard, M. \& G. Kataria (2011). Recreational angling markets to advance the conservation of a reach of the Western Ramganga River, India. Aquatic Conservation: Marine and Freshwater Ecosystems 21: 101-108.

FAO Recreational Fisheries (2012). FAO Technical Guidelines for Responsible Fisheries, No. 13. FAO, Rome, 176pp. 
Granek, E. F., E.M.P. Madin, M.A. Brown, W. Figueira, D.S. Cameron, Z. Hogan, G. Kristianson, P. de Villiers, J.E. Williams, J. Post, S. Zahn \& R. Arlinghaus (2008). Engaging recreational fishers in management and conservation: Global case studies. Conservation Biology 22: 1125-1134.

Gupta, N., P. Nautiyal, A. Borgohain, K. Sivakumar, V.B. Mathur \& M.A. Chadwick (2014). Catchand-release angling as a management tool for freshwater fish conservation in India. Oryx 50(2): 250-256; http://dx.doi.org/10.1017/S0030605314000787

Gupta, N., S.D. Bower, R. Raghavan, A.J. Danylchuk \& S.J. Cooke (2015a). Status of recreational fisheries in India: Development, issues, and opportunities. Reviews in Fisheries Science \& Aquaculture 23: 291-301.

Gupta, N., R. Raghavan, K. Sivakumar, V. Mathur \& A.C. Pinder (2015b). Assessing recreational fisheries in an emerging economy: Knowledge, perceptions and attitudes of catch-and-release anglers in India. Fisheries Research 165: 79-84.

Gupta, N., A. Rajvanshi, S. Sathyakumar, J.A. Johnson, K. Sivakumar, G.S. Rawat \& V.B. Mathur (2015c). Need for targeted education programme for preparedness and formulating adaptive strategies in the Indian Himalayan region. Current Science 109: 1233-1234.

Hasler, C.T., A.H. Colotelo, T. Rapp, E. Jamieson, K. Bellehumeur, R. Arlinghaus \& S.J. Cooke (2011). Opinions of Fisheries Researchers, Managers, and Anglers towards Recreational Fishing Issues: An Exploratory Analysis for North America. American Fisheries Society Symposium 75: 51-74.

Hunt, L. M., S.G. Sutton \& R. Arlinghaus (2013). Illustrating the critical role of human dimensions research for understanding and managing recreational fisheries within a social-ecological system framework. Fisheries Management and Ecology 20: 111-124.

Pereira, J. M., M. Petrere-Jr \& R.A. Ribeiro-Filho (2008). Angling sport fishing in Lobo-Broa reservoir (Itirapina, SP, Brazil). Brazilian Journal of Biology 68: 721-31.

Pinder, A. C., R. Raghavan \& R. Britton (2015). Efficacy of angler catch data as a population and conservation monitoring tool for the flagship Mahseer fishes (Tor spp) of Southern India. Aquatic Conservation: Marine and Freshwater Ecosystems 25(6): 829-838; http://dx.doi.org/10.1002/ aqc. 2543

Pinder, A. C., R. Raghavan \& R. Britton (2015). The legendary Humpbacked Mahseer Tor sp. of India's River Cauvery: An endemic fish swimming towards extinction. Endangered Species Research 28: 11-17.

Pinder, A.C. \& R. Raghavan (2013). Conserving the endangered Mahseers (Tor spp.) of India: the positive role of recreational fisheries. Current Science 104: 1472-1475.

Raghavan, R., A. Ali, N. Dahanukar \& A. Rosser (2011). Is the Deccan Mahseer, Tor khudree (Sykes, 1839) (Pisces: Cyprinidae) fishery in the Western Ghats Hotspot sustainable? A participatory approach to stock assessment. Fisheries Research 110: 29-38.

Suski, C. D., \& S.J. Cooke (2007). Conservation of aquatic resources through the use of freshwater protected areas: opportunities and challenges. Biodiversity and Conservation 16: 2015-2029.

Vishwanath, W., H.H. Ng, R. Britz, L.K. Singh, S. Chaudhry \& K.W. Conway (2010). The status and distribution of freshwater fishes of the Eastern Himalaya region, p. 90. In: Allen, D.J., S. Molur \& B.A. Daniel (comp.). The Status and Distribution of Freshwater Biodiversity in the Eastern Himalaya. IUCN, Cambridge, UK and Gland, Switzerland and Zoo Outreach Organisation, Coimbatore, India.
Author Contribution: NG and RR conceived the idea; NG carried out the online survey; NG, SDB, SJC, AJD and RR co-wrote the manuscript.

Author Details: NISHIKANT GUPTA's research involves investigating novel strategies for protecting and conserving the Indian Rivers from anthropogenic stressors and changing climatic variables. He is particularly interested in the mahseer fish species, especially the golden (Tor putitora) and the red-finned (Tor tor) mahseer found in the Indian Himalayan water bodies. SHANNON BOWER is a PhD candidate in the Fish Ecology and Conservation Physiology Laboratory at Carleton University in Ottawa, Canada. Her research interests include inland fisheries and aquatic conservation. Her current project focuses on developing rapid assessment tools for determining the long term viability of catch and release fisheries from biological, social, and economic perspectives. STEVEN J. COOKE is a Canada Research Chair and Associate Professor at Carleton University where he studies the ecology, physiology, and behaviour of wild fish. Much of his work is focused on recreational fisheries and the sustainable management of inland waters. ANDY J. DANYLCHUK is an Associate Professor at the University of Massachusetts Amherst. Spanning both marine and freshwater systems, his work combines life history theory, population dynamics, and physiology to understanding how fish are impacted by natural and anthropogenic disturbances. Over the past 15 years his work has focused on developing best practices for catchand-release recreational fisheries. RAJEEV RAGHAVAN is an Assistant Professor, and the South Asia Chair of the IUCN SSC Freshwater Fish Specialist Group. His research focuses on generating information and developing methods to support conservation decisionmaking in tropical freshwater ecosystems, with a special reference to the Western Ghats Hotspot.

Appendix I. Recreational Angling Survey

The aim of this survey is to determine the extent to which there is support from the recreational angling community in India for river and fish conservation.

1) What is your age?

2) What is your gender?

3) Which organization do you have main affiliation with?

4) On average, how many days do you fish per year in India?

5) Which Indian State/Union Territory do you live in?

6) Which Indian State/Union Territory do you mostly fish in?

7) How many days did you fish over the past year (June 1st 2013 to May 31st 2014) in this State/Union Territory?

8) Which is your main target fish species during angling?

9) Which is your preferred angling method?

10) Regarding your angling experience, which factor is most important to you?

11) In your opinion, which threat is impacting your target fish species and your leisure experience the most?

12) Which conservation effort do you feel need to be implemented to protect and conserve the fish biodiversity in India?

13) Have you witnessed destructive fishing techniques first hand at/near your angling location?

14) What were these destructive fishing techniques?

15) How much money do you spend per year towards recreational angling activities (in Indian Rupees)?

16) How many fish do you catch each year?

17) What percentage (\%) of those fish do you release back into the water?

18) How aware are you of the conservation status, e.g., endangered/vulnerable/near-threatened of the fish species you target?

19) Do you think that recreational angling can benefit the conservation of fish species in Indian rivers?

20) Please explain your answer to the above.

21) How willing would you be to get involved in a conservation initiative in your angling region?

22) Would you be willing to contribute your time and money for such an initiative?

23) Any additional comments/concerns. 